\title{
The Correlations Among Learning Strategy, Reading Interest and the Eighth Grade Students' Reading Comprehension of State Junior High School at Talang Ubi Sub-District of PALI Regency
}

\author{
Sinta Waluyojati ${ }^{1 *}$, Baginda Simaibang ${ }^{2}$, Mulyadi $^{2}$
}

\author{
${ }^{1}$ SMP N 1 Talang Ubi \\ ${ }^{2}$ Universitas PGRI Palembang \\ *Corresponding author. Email: sintawaluyojati75@gmail.com
}

\begin{abstract}
This thesis is concerned with the inquiry on the correlation among learning strategy, reading interest, and the eighth-grade students' reading comprehension of state junior high school at Talang Ubi sub-district of PALI regency. The study investigates the correlation among students' learning strategy, reading interest, and also reading comprehension. The numbers of the population were 1.247 students. The sample of this study was 82 students taken through a purposive sampling technique. Data were collected using a questionnaire for learning strategy and reading interest and a test for reading comprehension. Data were analyzed by using r-Product Moment and Multiple Regression. The finding showed that there are correlations among learning strategy, reading interest, and reading comprehension. The data analysis shows that Ryx $1 \times 2=0.762$ with $\mathrm{r} 2=0.305$ and the criteria of the significant test is gotten $F_{\text {count }}(4.043)>$ $F_{\text {table }}$ (3.111). Therefore, the alternative hypothesis $\left(H_{a}\right)$ is accepted while the null hypothesis $\left(H_{o}\right)$ is rejected. Conclusions suggest significant correlations among learning strategy, reading interest, and reading comprehension for the eighth-grade students of State Junior High School of Talang Ubi SubDistrict of PALI Regency.
\end{abstract}

Keywords: "Learning Strategy, Reading Interest, and Reading Comprehension."

\section{INTRODUCTION}

Reading is a process of communication from the author to the reader. [1] Reading, debatably the essential skill for achievement in all educational contexts remains a skill of dominant position as we make general language ability assessments. According to [2], reading can understand and construct the meaning from the text to get information. [3] Reading books' practice creates cognitive engagement that improves many things, including vocabulary, thinking skills, and concentration. It also can affect empathy, social perception, and emotional intelligence, the sum of which helps people stay on the planet longer.
Moreover, [4] said that reading is a bridge to comprehend or understand the text's material so that the students can catch the meaning or idea. In short, students can get information and expand their knowledge about what they are learning and what they need to know by reading. Through reading, students can improve their reading skills and develop their ability to use English. Reading can give them more information and knowledge that they need. In many cases, students' reading ability is still low, and students have some reading problems, especially to comprehend the text's meaning or message. They can read the text, but they do not understand the text's message or purpose. Because of that, they cannot answer the questions based on the text. Sometimes, 
they do not understand the text's topic, and sometimes the students get nothing from the text. [5] claimed, there are two processes involved in reading, namely word recognition and comprehension.

Based on researchers' observations and interviews with one of the English teachers at SMP Negeri 10 Talangubi PALI, English lessons are still not achieved the specified minimum completeness criteria or Kriteria Kelulusan Minimum (KKM). Any students do following the remedial after the reading comprehension ability test was carried out. This matter proves that the goal of learning reading comprehension skills has not been achieved well.

The English teacher of SMPN 10 Talang Ubi, also has problems in learning reading skills, especially reading comprehension. The first problem is about students do not know the suitable learning strategies for reading comprehension. Second, students' interest in reading is low, especially reading comprehension. Third, students cannot understand the reading text they read, and sometimes they got nothing from the text.

First is learning strategies; learning strategies are severe problems because strategy plays an essential role in achieving learning outcomes. A learning strategy is defined as "an individual's approach to a task that includes how a person thinks and acts when preparing, implementing, and assessing performance on an assignment and its outcomes."

Many people think about learning is done automatically. For instance, most of us unconsciously slow down when reading content that is hard for us to comprehend. Also, we use various strategies to organize and recollect - both key elements of the learning process. According to [6], "Learning strategies are on purpose behavior and thoughts that learners create a habit of learning to help them understand, learn, or remember new information better." This quotation shows learning strategies focus on specific characteristics of new information, analyzing and organizing information during the learning process to improve comprehension, and evaluating the learning process when accomplished to see if more activities are needed.

Second, reading interest is one of the students' internal factors that may significantly influence their reading ability. [7] claimed interest is generally classified as a situational interest, an individual interest, and a topic of interest: personal interest subsumes readers' interests for specific text themes or subjects. This interest occurs before reading a particular text. Situational interest refers to interest caused by situational factors, such as the text and the test; a specific situation may impact the situational interest and is therefore not enduring. Topical interest refers to the interest caused by a subject or theme. With contributions of either depending on the knowledge, experiences, and perceived value of a topic, it appears to share both situational and individual interest qualities. Moreover, reading is interested in whether learners like to read in their free time or go to the library. Besides, reading interest is also characterized by the number of books read and the number of times students read in a day, week, or month. Also, based on the favorite genres of English reading materials. It is supposed that students read not because they willing to read but then again because they have to read.

Third, reading comprehension is achieved from the knowledge or information. It also resulted from achieving the meaning that originated from grammar knowledge: understanding word form and relation among words in sentences. According to [8] defined, reading comprehension is constructing and extracting meaning at once through communication and connection with written language. Then, [9] explained that reading for general understanding refers to understanding information in a text and interpreting it correctly and adequately.

The relevant study was conducted by [10] with the title The Correlation among Vocabulary Mastery, Reading Interest and Reading Comprehension of the Eighth Grade Students' at SMP Ahmad Dahlan Kota Jambi. This graduating paper is conducted to find out the. This study shows a high correlation among students' reading interest, vocabulary mastery, and reading comprehension. It is confirmed by coefficient correlational among students' reading interest, vocabulary mastery, and reading comprehension was $\mathrm{r}$ (0.983), which means those variables were correlated significantly.

A research location is a place where the research was carried out to obtain the required data. The research was carried out in all State Junior High Schools throughout Talang Ubi Sub-District. However, only four schools open access to the researcher to collect the data because of covid-19. There are: SMP N 1Talang Ubi, SMP N 7 Talang 
Ubi, SMP N 9 Talang Ubi, SMP N 10 Talang Ubi. This study differs from previous studies because the population consists of one sub-district within the regency.

In line with the research problems above, this investigation is undertaken to find out whether or not: There is a significant correlation between (1) learning strategy and reading comprehension; (2) reading interest and reading comprehension; and (3) learning strategy and reading interest; Also, (4) There are significant correlations among learning strategy, reading interest, and reading comprehension for the eighth-grade students of State Junior High School of Talang Ubi SubDistrict of Pali Regency

\section{METHODS}

\subsection{Types of research}

In this study, the writer used quantitative research with a correlational design. A correlation study is a quantitative research method in which the writer has three quantitative variables from the same groups of subjects. This research was conducted to know the distribution of correlation between X1 and Y, X2 and Y, Y, X1, X2. Also, the correlation among $\mathrm{X} 1, \mathrm{X} 2$, and $\mathrm{Y}$.

This research answered the formulation of the problem, test the research hypothesis, and conclude the correlation among learning strategy (X1), reading interest (X2), and reading comprehension (Y) of the eighth-grade students of Junior High School of Talang Ubi Sub-District of Pali Regency.

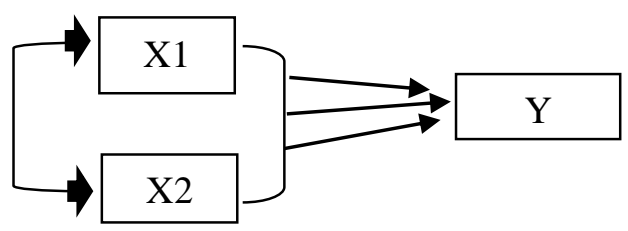

Figure 1. Research Design

(Adapted from Sugiyono, 2011)

1. Learning strategy correlates to reading comprehension

2. Reading interest correlate to reading comprehension

3. Learning strategy correlates to reading interest

4. Learning strategy and reading interest simultaneously correlate to reading comprehension
Notes:

$\mathrm{X} 1 \quad$ : Learning strategy

X2 : Reading Interest

Y : Reading Comprehension

\subsection{Research Subjects and Data}

The subjects in this study comprised eighth-grade students of State Junior High School of Talang-Ubi sub-district of PALI Regency. Sampling was taken through a purposive sampling technique. The sample of this study consists of 82 students. In this study, in collecting the data, the writer used two kinds of instruments (2) questionnaire and (1) reading test. In this study, the writer used a reading test to define the reading comprehension of students. Questionnaires of learning strategy and reading interest were used to assess students learning strategy and their interest in reading. The researcher applied the questionnaire to know how the students' reading strategy and interest measured students' interest in reading based on their learning English lessons. The instrument used had been validated through internal validity, construct validity. Construct validity from field trial results.

In this study, The trial results were analyzed used the statistic formula r-Product Moment and Multiple Regression. The statistic formula r-Product Moment was utilized to analyze data to answer the research problem: the first, the second, and the third. While Multiple Regression was applied to test whether variables $X_{1}$ (learning strategy), $\mathrm{X}_{2}$ (reading interest) have significant correlations with variable $\mathrm{Y}$ (reading comprehension). Multiple Regression analysis is intended to find out the correlations among three variables. 


\section{RESULTS AND DISCUSSION}

\subsection{Results}

1. The correlation between learning strategy and Reading comprehension (Research problem No. 1)

Table 1. The Correlation Between Students' Learning Strategy and Reading Comprehension Summary

\begin{tabular}{|l|l|c|c|}
\hline \multicolumn{4}{|c|}{ Correlations } \\
\hline \multicolumn{2}{|c|}{} & $\begin{array}{l}\text { Learning } \\
\text { Strategy }\end{array}$ & $\begin{array}{l}\text { Reading } \\
\text { Comprehension }\end{array}$ \\
\hline $\begin{array}{l}\text { Learning } \\
\text { Strategy }\end{array}$ & $\begin{array}{l}\text { Pearson } \\
\text { Correlation }\end{array}$ & 1 & $.293^{* *}$ \\
\cline { 2 - 4 } & Sig. (2-tailed) & & .007 \\
\cline { 2 - 4 } & $\mathrm{N}$ & 82 & 82 \\
\hline $\begin{array}{l}\text { Reading } \\
\text { Comprehe } \\
\text { nsion }\end{array}$ & $\begin{array}{l}\text { Pearson } \\
\text { Correlation }\end{array}$ & $.293^{* *}$ & 1 \\
\cline { 2 - 4 } & Sig. (2-tailed) & .007 & 82 \\
\cline { 2 - 4 } & $\mathrm{N}$ & 82 & \\
\hline \multirow{2}{*}{$* *$ Correlation is significant at the 0.01 level (2-tailed). } \\
\cline { 2 - 3 }
\end{tabular}

Table 1 above shows that the p-value Sig is 0.00 . This value is lower than 0.05 . This is significant. So, $\mathrm{Ha}$ is accepted while $\mathrm{Ho}$ is rejected. Therefore, there is a significant correlation between learning strategy and reading comprehension.

2. The correlation between Reading Interest and Reading comprehension (Research problem No. 2)

Table 2. The Correlation Between Students' Reading Interest and Reading Comprehension Summary

\begin{tabular}{|l|l|l|l|}
\hline \multicolumn{4}{|c|}{ Correlations } \\
\hline \multirow{2}{*}{} & $\begin{array}{l}\text { Reading } \\
\text { Comprehension }\end{array}$ & $\begin{array}{l}\text { Reading } \\
\text { Interest }\end{array}$ \\
\hline $\begin{array}{l}\text { Reading } \\
\text { Comprehens } \\
\text { ion }\end{array}$ & $\begin{array}{l}\text { Pearson } \\
\text { Correlation }\end{array}$ & 1 & $.293^{* *}$ \\
\cline { 2 - 4 } & $\begin{array}{l}\text { Sig. } \\
\text { tailed })\end{array}$ & & \\
\cline { 2 - 4 } & $\mathrm{N}$ & 82 & .008 \\
\hline \multirow{2}{*}{$\begin{array}{l}\text { Reading } \\
\text { Interest }\end{array}$} & $\begin{array}{l}\text { Pearson } \\
\text { Correlation }\end{array}$ & $.293^{* *}$ & 82 \\
\cline { 2 - 4 } & $\begin{array}{l}\text { Sig. } \\
\text { tailed) }\end{array}$ & .008 & 1 \\
\cline { 2 - 4 } & $\mathrm{N}$ & 82 & 82 \\
\hline \multirow{2}{*}{ **. Correlation is significant at the 0.01 level (2-tailed). } \\
\hline
\end{tabular}

Table 2 above shows that the p-value Sig is 0.00 . this value is lower than 0.05. This is significant. So, $\mathrm{Ha}$ is accepted while $\mathrm{Ho}$ is rejected. Therefore, there is a significant correlation between reading interest and reading comprehension.

3. The correlation between Students' Learning Strategy and Reading Interest (Research problem No. 3)

Table 3. The Correlation Between Students' Learning Strategy and Reading Interest Summary

\begin{tabular}{|c|c|c|c|}
\hline \multicolumn{4}{|c|}{ Correlations } \\
\hline & & $\begin{array}{l}\text { Reading } \\
\text { Interest }\end{array}$ & $\begin{array}{l}\text { Learning } \\
\text { Strategy }\end{array}$ \\
\hline \multirow{3}{*}{$\begin{array}{l}\text { Reading } \\
\text { Interest }\end{array}$} & Pearson Correlation & 1 & $.849^{* *}$ \\
\hline & Sig. (2-tailed) & & .000 \\
\hline & $\mathrm{N}$ & 82 & 82 \\
\hline \multirow{3}{*}{$\begin{array}{l}\text { Learning } \\
\text { Strategy }\end{array}$} & Pearson Correlation & $.849^{* *}$ & 1 \\
\hline & Sig. (2-tailed) & .000 & \\
\hline & $\mathrm{N}$ & 82 & 82 \\
\hline
\end{tabular}

Table 3 above shows that the p-value Sig is 0.00 . This value is lower than 0.05 . This is significant. So, $\mathrm{Ha}$ is accepted while Ho is rejected. Therefore, there is a significant correlation between Learning Strategy and reading interest.

4. The correlation among Students' Learning Strategy, Reading Interest and Reading Comprehension (Research problem No. 4)

Table 4. The Regression Among Students' Learning Strategy, Reading Interest and Reading Comprehension Summary

\begin{tabular}{|l|l|l|l|l|l|l|}
\hline \multicolumn{7}{|c|}{ ANOVA } \\
\hline \multirow{2}{*}{ Model } & Sum of Squares & Df & $\begin{array}{l}\text { Mean } \\
\text { Square }\end{array}$ & F & Sig. \\
\hline \multirow{2}{*}{1} & Regression & 999.400 & 2 & 499.700 & 4.043 & $.021^{\mathrm{b}}$ \\
\cline { 2 - 7 } & Residual & 9763.197 & 79 & 123.585 & & \\
\cline { 2 - 7 } & Total & 10762.598 & 81 & & & \\
\hline \multicolumn{7}{|l|}{ a. Dependent Variable: Reading Comprehension } \\
\hline \multicolumn{6}{|l|}{ b. Predictors: (Constant), Learning Strategy, Reading Interest } \\
\hline
\end{tabular}

Table 4 shows that the $\mathrm{p}$-Value is 0.02 . This value is lower than 0.05 . This is significant. So, $\mathrm{Ha}$ is accepted while $\mathrm{Ho}$ is rejected. Therefore, there is a significant correlation between learning strategy, reading interest, and reading comprehension. 


\subsection{Discussion}

The result from the first hypothesis testing is that there The result from the first hypothesis testing is that there was a very weak or little significant correlation between learning strategy (X1) and reading comprehension (Y). The result of $R_{y X 1}$ is 0.293 included in substantial interpretations, $\mathrm{X} 1$ and $\mathrm{Y}$ correlate $8.6 \%$. From the linear regression analysis, it was found that regression between $\mathrm{X} 1$ and $\mathrm{X} 2$ is of $T_{\text {count }}=$ $2.744>T_{\text {table }}=2.284$, it means that the variables were linear and significant. So, students' learning strategy is related to students' reading comprehension. Since the students have a good strategy for reading comprehension, it can influence the study's result.

The second hypothesis testing result showed a very weak or little significant correlation between reading interest (X2) and reading comprehension (Y). The result of $R_{y X 1}$ is 0.293 , which included substantial interpretations, $\mathrm{X} 2$ and $\mathrm{Y}$ correlation $8.6 \%$. From the linear regression analysis, it was found that regression between $\mathrm{X} 2$ and $\mathrm{Y}$ is of $T_{\text {count }}=2.738>T_{\text {table }}=2.284$, it means that the variables were linear and significant. Also, reading interest is characterized by the number of books read per month and the number of times students read per week, and by the preferred genres and form of English reading content.

The third hypothesis testing result showed a very high significant correlation between learning strategy (X1) and reading interest (X2). The result of $R_{y X 1}$ is 0.849 which included in substantial interpretations, $\mathrm{X} 1$ and $\mathrm{X} 2$ correlation $72,1 \%$. From the linear regression analysis, it was found that regression between $\mathrm{X} 1$ and $\mathrm{X} 2$ is of $T_{\text {count }}=$ $14.377>T_{\text {table }}=2.284$, it means that the variables were linear and significant. Furthermore, the great learning strategy you have it influence on your reading interest.

The result form the fourth hypothesis testing on the correlation and regression among learning strategy $(\mathrm{X} 1)$, reading interest $(\mathrm{X} 2)$, and reading comprehension (Y) with $R_{y X 1}$ is 0.305 . In line with the result, there was a very weak or little significant correlation among the three variables. From multiple regression analysis, it was found that regression among $\mathrm{X} 1, \mathrm{X} 2$, and $\mathrm{Y}$ is $F_{\text {Count }}$ (4.403) > $F_{\text {Table }}(3.111)$, it means that the variables were linear and significant. Then X1,
$\mathrm{X} 2$, and $\mathrm{Y}$ correlate $9.3 \%$. Students need to learn further by reading extensively to have reading comprehension. It's not an easy thing to do, though. Students need to have the pleasure, the willingness, the consciousness, and the attention to do it. Then, by a good learning strategy, a reader might be interested in reading texts.

\section{CONCLUSION}

In line with the findings in the previous chapter, the following conclusions can be drawn as follows: There is a significant correlation between (1) learning strategy and reading comprehension; (2) reading interest and reading comprehension; (3) learning strategy and reading interest; and (4) learning strategy, reading interest, and reading comprehension of the eighth-grade students of Junior High School of Talang Ubi SubDistrict of Pali Regency for the fourth problem.

\section{REFERENCES}

[1]. Brown.H., Douglas. 2004. Language Assessment Principle and Classroom Practices.New York: Pearson Education, Inc.

[2]. Herlina. (2018). Teaching Reading through Speed Reading Techniques. English Empower. Vol.03 (01)

[3]. Desmarais, C. 2018. Why Reading Books Should Be Your Priority. Contributor, Inc.com. Retrieved from https://www.inc.com/christinadesmarais/why-reading-books-shouldbe-your-priority-according-toscience.html

[4]. Mortini, A. V. (2017). Teaching Reading Descriptive text through Jeopardy Game to the Eighth Grade Students of State Junior High School 20 of Palembang. Jambi-English Language Teaching Journal. Vol. 02 (01), 13-17

[5]. Elizabeth S. Pang, et al.,(2003), Teaching Reading, Switzerland: The International

[6]. Richards, J. C, Platt, J. \& Platt, H. (1992). Longman dictionary of language teaching and applied linguistics. Harlow: Longman

[7]. Eidswick, J. (2009). The influence of 
interest on reading comprehension in EFL students. Annual Research Report of the Language Center, 12, 25-38. Kwansei Gakuin University

[8]. Snow, Catherine. (2002). Reading for Understanding: Toward an R\&D Program in Reading Comprehension. Los Angeles: RAND.

[9]. Grabe, W. \& Stoller, F, L. 2002. Teaching and Researching Reading. England: Pearson. Education Limited.

[10].Devi Oktaviani (2019). The Correlation Among Vocabulary Mastery, Reading Interest, And Reading Comprehension of The Eighth Grade Student's At Smp Ahmad Dahlan Kota Jambi 